\title{
PENGARUH KEMAMPUAN KERJA DAN KEPUASAN KERJA TERHADAP KINERJA KARYAWAN PADA PERUSAHAAN DAERAH (PD) PASAR KABUPATEN BULELENG
}

\author{
S. A. Effendy ${ }^{1}$, I N. Suarmanayasa ${ }^{2}$ \\ 1,2,3 Jurusan Mananjemen, Universitas Pendidikan Ganesha, Singaraja \\ e-mail: audryshimaefendy@gmail.com¹, nengah.suarmanayasa@undiksha.ac.id²
}

\begin{abstract}
Abstrak
Riset ini berdestinasi untuk menguji poin-poin berikut: (1) pengaruh keahlian kerja serta kepuasan kerja terhadap kinerja pegawai, (2) pengaruh keahlian kerja terhadap kinerja pegawai, (3) pengaruh kepuasan kerja terhadap kinerja pegawai; (4) Pengaruh keahlian kerja terhadap kepuasan kerja (PD) industri wilayah). Pasar Kabupaten Paulin( Buleleng). Desain studi yang digunakan dalam studi ini merupakan kuantitatif kausal. Destinasi studi ini merupakan keahlian kerja, kepuasan kerja serta kinerja karyawan. Subjek studi merupakan segala karyawan Industri Kecamatan Pasar Buleleng (PD) Kabupaten Pasar Buleleng dengan banyaknya populasi 32 orang. Tata cara pengumpulan informasi yang digunakan merupakan kuesioner. Metode analisis yang digunakan merupakan analisis jalan. Capaian studi menampilkan kalau: (1) kemampuan kerja serta kepuasan kerja berakibat positif terhadap kinerja karyawan, (2) kemampuan kerja berakibat positif terhadap kinerja karyawan, (3) kepuasan kerja berakibat positif terhadap kinerja karyawan, serta (4) Kemampuan kerja berakibat positif terhadap kepuasan kerja industri wilayah( Kabupaten Pasar Buleleng).
\end{abstract}

Kata kunci: kemampuan kerja, kepuasan kerja, kinerja karyawan

\begin{abstract}
This study aims to examine the effects of: (1) job ability and job satisfaction on employee performance, (2) work ability on employee performance, (3) job satisfaction on employee performance and (4) job ability on job satisfaction at Perusahaan Daerah (PD) Pasar Kabupaten Buleleng. The research design used in this research is causal quantitative. The object of this research were job ability, job satisfaction and employee performance. The research subjects were all employees of Perusahaan Daerah (PD) Pasar Kabupaten Buleleng with a population of 32 people. The data collected by the method of recording documents and questionnaires. The analysis technique is used by path analysis. The results showed that: (1) job ability and job satisfaction has a positive and significant effect on employee performance (2) job ability has a positive and significant effect on employee performance, (3) job satisfaction has a positive and significant effect on employee performance and (4) ability work has a positive and significant effect on job satisfaction at Perusahaan Daerah (PD) Pasar Kabupaten Buleleng
\end{abstract}

Keywords: employee performance, job ability, job satisfaction

\section{Pendahuluan}

Kebutuhan masyarakat dalam melakukan transaksi dan memperoleh komoditas yang dibutuhkan memerlukan suatu tempat yang dapat memuaskan baik pembeli maupun penjual, yang biasa disebut pasar. Pasar yang didirikan serta dikelola oleh pemerintah, pemerintah wilayah, swasta, BUMN serta BUMD, tercantum kemitraan pihak swasta berbentuk pertokoan, kios, stand serta tenda yang dipunyai ataupun dikelola oleh organisasi kecil, menengah, serta non pemerintah, usaha kecil, modal kecil serta koperasi yang membeli serta menjual benda lewat tawar- menawar.

Dalam rangka memenuhi permintaan masyarakat akan ketersediaan pasar maka perlu dilakukan pengelolaan pasar dengan memberikan arahan dan kebijakan terkait penjualan produk atau jasa. Pengelolaan pasar di Indonesia dilakukan oleh Badan Usaha Milik Daerah (BUMD) yang bergerak dalam bidang pengabdian kepada masyarakat dalam rangka mewujudkan pasar tradisional, sarana dan prasarana. Badan Usaha Milik Daerah (BUMD) yang mengelola pasar disebut pasar Perusahaan Daerah (PD). Perusahaan Daerah (PD) Pasar Buleleng merupakan salah satu perusahaan pasar yang berlokasi di Anggrek 7 Jalan 
Singaraja yang saat ini pasarnya ada tidak hanya untuk pemerintah daerah atau pusat tetapi juga bagi mereka yang mengandalkannya untuk kegiatan perdagangan. Dalam melaksanakan operasional Perusahaan Daerah (PD) Pasar Buleleng, dibutuhkan sumber daya manusia yang kompeten untuk membantu perusahaan bekerja lebih cepat dan profesional. Setiap perusahaan selalu menginginkan karyawannya meningkatkan performa. Kebercapaianan karyawan diukur dari performa. Performa didampaki oleh banyak faktor, termasuk kemampuan dan kepuasan kerja. Perihal tersebut ditegaskan oleh Nuriasih (2016: 42) Statment tersebut melaporkan kalau karyawan dengan keahlian kerja yang lebih besar serta kepuasan kerja hendak tingkatkan kinerja karyawan yang berakibat pada kenaikan pemasukan industri. Mengenai ini pula didukung oleh studi yang dicoba oleh Saputra Gumi, dkk( 2019) yang menampilkan kalau keahlian kerja serta kepuasan kerja berakibat substansial terhadap kinerja karyawan.

Namun perihal ini berbanding terbalik dengan kondisi Perusahaan Daerah (PD) Pasar Kabupaten Buleleng yang mengalami performa yang rendah. Dalam mengukur performa karyawan dapat diamati dari peningkatan pendapatan yang dicapai. Adapula daftar capaian pendapatan dua tahun terakhir dari 2017 dan 2018 capaian observasi awal pada bagian pendapatan di Perusahaan Daerah (PD) Pasar Kabupaten Buleleng. Perihal tersebut menampakkan belum tercapainya target pada tahun 2018 Perusahaan Daerah (PD) Pasar Kabupaten Buleleng dibandingkan dengan Kota Denpasar. Dari perihal tersebut dapat kita lihat bahwa performa karyawan pada Perusahaan Daerah (PD) Pasar Kabupaten Buleleng sangat rendah. Dalam observasi performa karyawan tersebut terdapat indikator performa karyawan yang perlu diketahui oleh pihak pembinaan SDM, Pasar Perusahaan Daerah (PD) meliputi capaian pekerjaan bagaikan berikut: meliputi banyaknya capaian kerja dan kualitas capaian kerja; perilaku kerja meliputi pengembangan gagasan dan loyalitas karyawan kepada perusahaan; dan kualitas pribadi, termasuk pelaksanaan tugas yang tidak terorganisirkaryawan bantuan, wawasan karyawan tentang pekerjaan dan pekerjaan yang dilakukan dengan rekan kerja.

Bersumber data observasi awal dari performa karyawan dapat diketahui bahwa total perolehan skor berada dalam kategori rendah. Dari data ini dapat diamati bahwa sebagian besar responden menguttarakan performa karyawan rendah disebabkan oleh kemampuan kerja dan kepuasan kerja karyawan yang kurang dimaksimalkan. Dari observasi awal riset, pihak Kasie, pengembangan dan pembinaan SDM mengeluhkan para karyawan sering melakukan kesalahan dalam melaksanakan tugasnya padaperihal pelatihan sudah sering sekali dilaksanakan untuk memberikan pemahaman kepada karyawan. Kurangnya kemampuan kerja yang dimiliki karyawan sangat berdampak pada performa. Perihal ini sejalan dengan Widodo (2004) yang menguttarakan bahwa diperlukan ketrampilan dan ketrampilan yang tinggi (profesionalisme) dan memiliki beberapa syarat dalam melakukan pemerintahan, pembangunan, dan pengabdian kepada masyarakat. Oleh sebab itu, penyelenggaraan negeri bisa digolongkan bagaikan profesi, serta tidak seluruh orang bisa menyelenggarakan penyelenggaraan negeri kecuali yang berpendidikan lebih besar serta pengalaman, keahlian, keahlian, serta kebolehan yang mencukupi. Kemampuan kerja menunjang meningkatnya performa karyawan sehingga perusahaan perlu memberikan kepuasan kerja untuk memaksimalkan perihal tersebut. Perihal ini sejalan dengan capaian riset Imam (2017) menampakkan bahwa kemampuan kerja memdampaki performa karyawan. Pada Perusahaan Daerah (PD) Pasar Kabupaten Buleleng kemampuan karyawan masih dibesaran rendah.

Bersumber observasi tersebut menampakkan bahwa total perolehan skor berada dalam kategori rendah dengan capaian skor keseluruhan observasi awal sebesar 144 termasuk kedalam kategori rendah. Dimana karyawan masih mengalami masalah keterampilan dalam berkomunikasi dengan banyak orang, kurangnya kerjasama antar rekan kerja serta ditemukan karyawan yang kurang berpengalaman dalam bekerja. Kurangnya kemampuan kerja ini disebabkan pula karena ketidakpuasan karyawan dalam bekerja karena pihak perusahaan belum memenuhi pemberian bonus dan intesentif sesuai dengan pekerjaan yang dilaksanakan oleh masing-masing individu. Penghargaan kepada karyawan sangat jarang diberikan sehingga 
perihal ini menimbulkan karyawan enggan dalam meningkatkan kemampuan kerja. Perihal ini juga diuttarakan oleh Darmawan (2013) yang menguttarakan karyawan yang memiliki kemampuan kerja yang sepadan akan mengharapkan kepuasan kerja untuk menjamin terpenuhnya kebutuhan yang dimiliki. Kemampuan kerja akan menunjang meningkatnya performa karyawan sehingga perusahaan perlu memberikan kepuasan kerja untuk memaksimalkan perihal tersebut.

Bersumber observasi awal dari kepuasan kerja menampakkan total perolehan skor berada dalam kategori rendah dengan capaian skor keseluruhan observasi awal sebesar 68 termasuk kedalam kategori rendah. Dimana perusahaan belum memenuhi kebutuhan karyawan sesuai dengan standar yang telah ditetapkan misalnya pemberian insentif dan penghargaan terhadap karyawan yang berprestasi. Selain itu, suasana kerja masih cendurung kurang kondusif karena masih menerapkan sistem senioritas sehingga untuk karyawan yang baru bekerja merasa tertekan dan mendapatkan tugas yang lebih banyak. Bagi studi Darmawan (2013), kebutuhan karyawan terpenuhi sehingga mereka merasakan kepuasan kerja yang lebih besar yang hendak berakibat pada performa mereka. Untuk industri, berarti buat mencermati kebutuhan karyawan, semacam membagikan proteksi keselamatan, pemberian reward serta peluang kerja buat meningkatkan potensinya, membagikan reward serta peluang kerja buat meningkatkan potensinya, membagikan peluang buat berhubungan serta membolehkan karyawan buat berpartisipasi dalam kesempatan pengambilan keputusan. Capaian studi Sajangbati (2013) serta Sahlan (2014) pula meyakinkan Mengenai tersebut. Capaian studi menampilkan kalau kepuasan kerja berakibat terhadap performa karyawan.

Rendahnya performa karyawan di Perusahaan Daerah (PD) pasar Kabupaten Buleleng diindikasikan karena kemampuan karyawan yang kurang baik dan rendahnya kepuasan kerja karyawan. Menurut Robbins (Robbins, 2001) kesesuaian kemampuan kerja secara langsung memdampaki performa dan kepuasan karyawan. Indikator kemampuan adalah: (1) keterampilan teknis meliputi kemampuan menggunakan pengetahuan dan alat yang diperlukan, (2) keterampilan sosial meliputi kemampuan bekerja secara efektif dengan rekan kerja dan saling memotivasi, (3) kemampuan konseptual (Conceptual skill) merupakan kemampuan menghadapi permasalahan dan kemampuan dalam kompleksitas organisasi secara menyeluruh.

Bagi Robbins (Robbins, 2003), kepuasan kerja merupakan perilaku universal warga terhadap pekerjaan, yang menampilkan perbandingan antara banyaknya penghargaan yang diterima pekerja serta banyaknya penghargaan yang sepatutnya mereka terima. Penanda kepuasan kerja merupakan: (1) pekerjaan itu sendiri, (2) keadaan kerja serta (3) rekan kerja. Performa merupakan dimensi capaian kerja individu, sikap serta sikap. Performa adalah evaluasi terhadap karakter, perilaku atau pencapaian seseorang, bagaikan dasar pengambilan keputusan dan rencana pengembangan personel. Mangkunegara (2007) mengemukakan kalau performa bisa diukur bersumber mutu serta kuantitas pekerjaan yang dicoba oleh karyawan dalam melakukan tugasnya, serta bersumber tanggung jawabnya kepada karyawan yang bersangkutan. Bersumber pemikiran tersebut bisa disimpulkan kalau kemampuan serta kepuasan kerja berakibat terhadap performa karyawan. Adapun tujuan dari penelitian ini adalah untuk menguji pengaruh: (1) Kemampuan kerja dan kepuasan kerja terhadap kinerja karyawan pada Perusahaan Daerah (PD) Pasar Kabupaten Buleleng, (2) Kepuasan kerja terhadap kinerja karyawan pada Perusahaan Daerah (PD) Pasar Kabupaten Buleleng, (3) Kemampuan terhadap kepuasan kerja pada Perusahaan Daerah (PD) Pasar Kabupaten Buleleng, (4) Kemampuan terhadap kepuasan kerja pada Perusahaan Daerah (PD) Pasar Kabupaten Buleleng. Adapula manfaat yang diharapkan dalam riset ini adalah (1) Manfaat Teoritis, secara teoritis diharapkan capaian riset ini dapat membantu penerapan ilmu ekonomi khususnya dalam bidang manajemen sumber daya manusia, dan diharapkan capaian kajian tersebut dapat dijadikan acuan untuk riset selanjutnya. (2) Manfaat praktis, secara praktis diharapkan riset ini dapat memberikan masukan dan kontribusi pemikiran kepada Perusahaan Daerah (PD) Pasar Kabupaten Buleleng, khususnya dalam upaya peningkatan kinerja mengenai kemampuan dan kepuasan kerja. 


\section{Metode}

Tipe riset yang dimanfaatkan dalam riset ini adalah riset kuantitatif. Desain riset ini adalah desain riset kausal. Hubungan kausal ini dirancang untuk menguji hubungan kausal antara variabel yang berdampak dan variabel yang terdampak (Sugiyono, 2014: 56). Variabel independen yang diimanfaatkan dalam riset ini antara lain: kemampuan (X1), kepuasan kerja (X2). Variabel terikat (variabel terikat) yang diimanfaatkan adalah performa karyawan (Y).Subjek riset ini adalah karyawan Perusahaan Kecamatan (PD) Pasar Buleleng. Sedangkan objek riset ini adalah kemampuan kerja (X1), kepuasan kerja (X2) dan performa karyawan (Y). Populasi adalah wilayah yang digeneralisasikan, termasuk objek atau topik dengan kualitas dan karakteristik tertentu. Pengkaji menentukan apa yang akan diteliti dan kemudian menarik kesimpulan tentang objek atau topik tersebut (Ananta et al., 2014: 79). Populasi dalam riset ini adalah 32 orang karyawan di pasar Perusahaan Daerah (PD) Kabupaten Buleleng yang masih aktif beroperasi. Untuk memperjelas data yang ada di lapangan maka perlu dilakukan pendataan.

Tata cara pengumpulan data dalam riset ini menggunakan kuisioner. Kuesioner dalam riset harus memenuhi persyaratan validitas dan reliabilitas. Jika kuesioner dapat mengungkapkan isi yang diukur dengan kuesioner tersebut, maka kuesioner tersebut dinyatakan valid. Sebelum diimanfaatkan untuk mengumpulkan data, harus dilakukan pengujian. Menurut Sugiyono (2007), jika koefisien korelasi antar item lebih besar dari 0,30, dan tingkat kesalahan a sebesar 0,05 maka instrumen tersebut efektif. Sedangkan alat uji reliabilitas terkait dengan masalah kepercayaan alat riset. Jika besaran Croncbach Alpha dari struktur atau variable $>0,60$ dianggap reliabel. Untuk membantu memproses data untuk pengujian validitas, Program Paket Statistik IImu Sosial (SPSS) Windows 22.0 diimplementasikan. Tata metode analisis informasi dalam studi ini memakai analisis jalur. Analisis jalur diimanfaatkan untuk mengenali akibat langsung serta tidak langsung dari variabel independen serta variabel dependen. Dengan anggapan apanila informasi variabel kemampuan kerja, kepuasan kerja serta performa karyawan yang diperoleh dari capaian survei kuisioner ialah informasi yang diurutkan, serta informasi yang diimanfaatkan untuk meyakinkan keabsahan hipotesis wajib berbentuk informasi interval, maka perlu dilakukan konversi data tersebut menjadi interval dan lulus MSI untuk penskalaan.

\section{Hasil Dan Pembahasan}

Bersumber capaian perhitungan uji statistik analisis jalur, dengan dorongan program Social Science Statistical Aplikasi Package (SPSS) 22. 0 for Windows diperoleh capaian perhitungan SPSS pada Tabel 1

Tabel 4.1

Output SPSS Analisis Jalur Pengaruh Kemampuan Kerja dan Kepuasan Kerja Terhadap Kinerja Karyawan pada PD Pasar Kabupaten Buleleng

\begin{tabular}{ccccc}
\hline Parameter & Koefisien & P-Value & Alpha $(\alpha)$ & Keputusan \\
\hline $\mathrm{Ryx}_{1} \mathrm{x}_{2}$ & 0,924 & 0,000 & 0,05 & Menolak Ho \\
$\mathrm{R}^{2} \mathrm{yx}_{1} \mathrm{x}_{2}$ & 0,854 & - & 0,05 & - \\
$\mathrm{Px}_{1} \mathrm{x}_{2}$ & 0,798 & 0,000 & 0,05 & Menolak Ho \\
$\mathrm{P}^{2} \mathrm{x}_{1} \mathrm{x}_{2}$ & 0,637 & - & 0,05 & - \\
$\mathrm{Pyx}_{1}$ & 0,717 & 0,000 & 0,05 & Menolak Ho \\
$\mathrm{P}^{2} \mathrm{yx}_{1}$ & 0,514 & - & 0,05 & - \\
$\mathrm{Pyx}_{2}$ & 0,448 & 0,011 & 0,05 & Menolak Ho \\
$\mathrm{P}^{2} \mathrm{yx}_{2}$ & 0,207 & - & 0,05 & - \\
$\mathrm{Px}_{2} \varepsilon_{1}$ & 0,363 & - & - & - \\
$\mathrm{Py}_{2}$ & 0,146 & - & - & - \\
\hline
\end{tabular}


Pengaruh masing-masing variabel dapat dilihat pada Gambar 1.

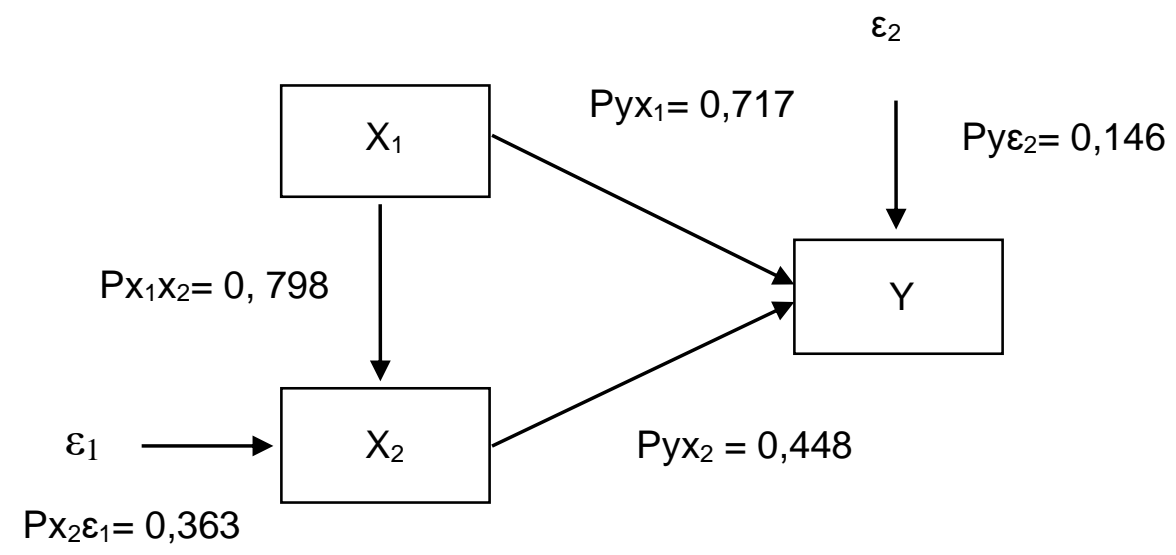

\section{Gambar 1. \\ Struktur Pengaruh Kemampuan Kerja dan Kepuasan Kerja Terhadap Kinerja Karyawan pada PD Pasar Kabupaten Buleleng}

Besar sumbangan pengaruh langsung dan tidak langsung dalam penelitian ini dapat dilihat pada Tabel 2.

Tabel 2.

Sumbangan Pengaruh Kemampuan Kerja dan Kepuasan Kerja Terhadap Kinerja Karyawan pada PD Pasar Kabupaten Buleleng

\begin{tabular}{lcc}
\hline Keterangan & Besar & Persentase \\
\hline Besar pengaruh langsung $\mathrm{X}_{1}$ terhadap $\mathrm{Y}$ & 0,514 & $51,4 \%$ \\
Besar pengaruh tidak langsung $\mathrm{X}_{1}$ & 0,357 & $35,7 \%$ \\
terhadap $Y$ melalui $\mathrm{X}_{2}$ & & \\
Besar pengaruh total $\mathrm{X}_{1}$ terhadap $\mathrm{Y}$ & 0,973 & $97,3 \%$ \\
Besar pengaruh langsung $\mathrm{X}_{2}$ terhadap $\mathrm{Y}$ & 0,207 & $20,7 \%$ \\
Besar pengaruh total $\mathrm{X}_{1}$ dan $\mathrm{X}_{2}$ terhadap $\mathrm{Y}$ & 0,854 & $85,4 \%$ \\
Besar pengaruh lain terhadap $\mathrm{Y}$ & 0,146 & $14,6 \%$ \\
Total & 1,000 & $100 \%$ \\
\hline
\end{tabular}

Bersumber capaian kalkulasi pengujian statistik analisis jalur yang dilakukan dengan program SPSS 22.0 for Windows diperoleh capaian bahwa Ryx1x2 $=0.924, \mathrm{p}$ value $=0.000$ $<$ alpha 0.05 , sehingga diputuskan untuk menolak Ho. Artinya kemampuan kerja (X1) dan kepuasan kerja (X2) berdampak positif dan substansial terhadap performa karyawan (Y) PD Pasar Kabupaten Buleleleng. Hal ini menampakkan dampak langsung kemampuan kerja (X1) dan kepuasan kerja (X2) terhadap performa karyawan $(\mathrm{Y})$ sebesar 0,854 atau $85,4 \%$. Perihal ini sesuai dengan teori yang diuttarakan oleh Robbins (2001) yang mengutarakan bahwa kesesuaian kemampuan kerja berdampak langsung terhadap performa dan kepuasan karyawan. Perihal tersebut ditegaskan oleh Nuriasih (2016: 42) Pernyataan tersebut mengutarakan bahwa karyawan dengan kemampuan kerja yang lebih tinggi dan kepuasan kerja akan meningkatkan performa karyawan yang akan berdampak pada peningkatan pendapatan PD Pasar Kabupaten Buleleng. Capaian riset ini mendukung riset yang dilakukan oleh Gumi et al. (2019) yang menampakkan bahwa kemampuan kerja dan kepuasan kerja berdampak terhadap performa karyawan. Kemampuan kerja karyawan diperoleh melalui pendidikan, pelatihan atau pengembangan untuk terlibat dalam pekerjaan tertentu, dan 
kepuasan kerja terkait dengan kebutuhan karyawan, seperti penghargaan dan keamanan kerja yang diberikan oleh PD Pasar Kabupaten Bulleleng. Perihal tersebut sependapat dengan capaian riset yang diperoleh. Capaian riset ini dibuktikan dengan belum tercapainya standar performa yang telah ditetapkan PD Pasar Kabupaten Buleleng sebelumnya. Jika diamati dari sisi kemampuan kerja, karyawan masih mengalami masalah keterampilan dalam berkomunikasi dengan banyak orang serta ditemukan karyawan yang kurang berpengalaman dalam bidang yang telah ditentukan. Kurangnya kemampuan kerja disebabkan karena kepuasan kerja karyawan belum terpenuhi, PD Pasar Kabupaten Buleleng belum memenuhi pemberian insentif dan penghargaan terhadap karyawan yang berprestasi. Oleh karena itu, PD Pasar Kabupaten Buleleng perlu dievaluasi dan ditingkatkan untuk meningkatkan kemampuan kerja dan mencapai kepuasan kerja guna mengoptimalkan performa karyawan untuk mencapai destinasi yang telah ditetapkan. Hal ini memberikan implikasi bahwa peningkatan kemampuan kerja dan terpenuhinya kepuasan kerja tentunya mampu memberikan kenyamanan dan rasa semangat dalam bekerja bagi karyawan. Dengan perihal tersebut karyawan akan memaksimal performa yang dimiliki untuk memberikan kontribusinya kepada perusahaan. Upaya peningkatan kemampuan kerja dan kepuasan kerja yang telah dilakukan diantaranya dengan memberikan pelatihan kepada karyawan dua kali dalam setahun dan pemberian insentif pada akhir tahun. Upaya tersebut masih belum optimal sehingga perlu upaya lain yang berdestinasi untuk meningkatkan kemampuan kerja dan kepuasan kerja karyawan diantaranya melakukan evaluasi terkait kebijakan sebelumnya sehingga kemampuan kerja karyawan dapat ditingkatkan. Pemberian pelatihan dapat dilakukan setiap satu bulan sekali dengan menyesuaikan kebutuhan keterampilan yang belum dimiliki karyawan. Sedangkan kepuasan kerja dapat diberikan setiap satu bulan sekali dengan melihat standar performa karyawan yang berprestasi.

Bersumber capaian kalkulasi uji statistik analisis jalur dengan bantuan program Windows SPSS 22.0, diperoleh capaian Pyx $1=0,717$ dengan besaran $P=0,000<$ alpha 0,05 , jadi keputusannya adalah menolak apa Artinya Kemampuan Kerja (X1) berdampak positif dan substansial terhadap performa karyawan PD Pasar Buleleng (Y). Hal ini menampakkan dampak langsung kemampuan kerja (X1) terhadap performa karyawan (Y) sebesar 0,514 atau $51,4 \%$, sehingga total dampak kemampuan kerja (X1) terhadap performa karyawan (Y) sebesar 0,973 atau 97,3\%. Mengenai ini tepat dengan teori yang diuttarakan oleh Widodo (2004: 51) ialah dalam penyelenggaraan pemerintahan, pembangunan serta dedikasi kepada warga memerlukan keahlian serta keterampilan yang besar (profesionalisme) serta mempunyai sebagian ketentuan. Oleh sebab itu, penyelenggaraan negeri bisa digolongkan bagaikan profesi. Tidak seluruh orang bisa menyelenggarakan penyelenggaraan negeri kecuali yang berpendidikan besar serta mempunyai pengalaman, keahlian, keahlian, serta kemampuan yang mencukupi. Mengenai ini sejalan dengan pemikiran Martoyo (2006) yang menarangkan kalau terus menjadi baik kemampuan kerja seseorang karyawan hingga terus menjadi besar pula performa karyawan tersebut. Capaian studi ini menunjang studi yang dilakukan oleh Imam (2017) yang menampakkan kalau kemampuan kerja berakibat terhadap performa karyawan. Kemampuan kerja sangat penting diperhatikan untuk meningkatkan produktivitas dalam bekerja. Perihal tersebut akan mampu mendorong PD Pasar Kabupaten Buleleng dalam mencapai destinasi yang telah ditetapkan. Rendahnya kemampuan kerja dapat diamati dari kemampuan karyawan dalam yang belum memiliki inisiatif dalam mengevaluasi dan meningkatkan performa dengan strategi-strategi baru. Penguasaan informasi karyawan masih kurang sehingga informasi yang diberikan kurang cepat dan tepat yang menyebabkan pelayanan belum optimal. Oleh karena itu, pihak PD Pasar Kabupaten Buleleng perlu melakukan melaksanakan evaluasi kemampuan karyawan dengan memberikan lebih banyak pelatihan dari ketentuan sebelumnya. Dampak langsung kemampuan kerja (X1) memberikan kontribusi lebih besar terhadap performa karyawan dibandingkan dampak tidak langsung. Perihal tersebut dikarenakan dengan pemberian pelatihan untuk meningkatkan kemampuan kerja dalam pelayanan akan membuat karyawan melakukan pekerjaan dengan sungguhsungguh sehingga pencapaian standar kerja dapat tercapai. Tercapainya standar kerja pada PD Pasar Kabupaten Buleleng akan membuat para karyawan mendapatkan penghargaan dam

Bisma: Jurnal Manajemen | 213 
insentif sehingga kepuasan karyawan terpenuhi. Hal ini memberikan implikasi bahwa kemampuan kerja diperlukan untuk meningkatkan performa karyawan. Oleh karena itu, PD Pasar Buleleng harus melakukan berbagai upaya untuk meningkatkan kemampuan kerjanya. Upaya yang telah dilakukan oleh pihak PD Pasar Kabupaten Buleleng diantaranya melakukan evaluasi kemampuan karyawan dan pemberian pelatihan hanya satu kali dalam setahun. Upaya tersebut dibesaran kurang optimal dalam meningkatkan kemampuan karyawan sehingga PD Pasar Kabupaten Buleleng perlu melaksanakan evaluasi kemampuan karyawan dalam memberikan informasi dan menangani keluhan dari masyarakat setidaknya dilaksanakan setiap satu bulan sekali dan pelatihan kemampuan bisa dilaksanakan lebih sering yaitu tiga bulan sekali untuk menguji profesional bekerja dari karyawan.

Bersumber capaian kalkulasi uji statistik analisis jalur yang dilakukan dengan bantuan program Windows SPSS 22.0, diperoleh capaian Pyx $1=0,448$ ketika $p$ value $=0,000<$ alpha 0,05 , sehingga diputuskan untuk menolak saya t. Artinya kepuasan kerja (X2) berdampak positif dan substansial terhadap performa karyawan PD Pasar Kabupaten Buleleng (Y). Kontribusi kepuasan kerja (X2) terhadap performa karyawan (Y) sebesar 0,200 atau $20 \%$. Mengenai ini cocok dengan teori yang diuttarakan oleh S Darmawan (2013) yang menguttarakan kalau kebutuhan karyawan terpenuhi sehingga kepuasan kerja terus menjadi besar yang hendak berakibat pada performa mereka. Capaian studi ini menunjang studi yang dilakukan oleh Sajangbati (2013) serta Sahlan (2014) yang menampakkan kalau kepuasan kerja berakibat terhadap performa karyawan. Karyawan dengan kepuasan kerja besar mempunyai tingkatan kerja yang positif, sebaliknya karyawan yang tidak puas dengan pekerjaannya mempunyai perilaku negatif terhadap pekerjaan. Bagi PD Pasar Buleleng perlu memperhatikan kebutuhan karyawan, seperti memberikan perlindungan keselamatan, pemberian reward dan kesempatan kerja untuk mengembangkan potensinya, memberikan reward dan kesempatan kerja untuk mengembangkan potensi dirinya, serta memberikan interaksi dan partisipasi dengan karyawan Kesempatan untuk membuat keputusan. Perihal tersebut sependapat dengan capaian riset yang diperoleh. Capaian riset ini dibuktikan dengan belum tercapainya standar performa yang telah ditetapkan PD Pasar Kabupaten Buleleng sebelumnya. Jika diamati dari sisi kepuasan kerja, karyawan kurang merasa puas dengan insentif yang diberikan tidak sesuai dengan pekerjaan yang telah dilakukan. Disamping itu, kurangnya apresiasi dan penghargaan terhadap karyawan berprestasi memicu karyawan tidak bersemangat untuk bekerja. Oleh karena itu, pihak PD Pasar Kabupaten Buleleng perlu melakukan perbaikan dan evaluasi terkait kebijakan dalam memberikan kepuasan kerja khususnya dalam pemberian insentif dan penghargaan kepada karyawan. Perihal ini akan membantu PD Pasar Kabupaten Buleleng untuk mencapai destinasi jangka pendek dan jangka panjang sekaligus mewujudkan visi bersama. Hal ini memberikan implikasi bahwa kepuasan kerja mampu memengaruhi performa karyawan untuk lebih bersemangat dan melaksanakan tanggungjawabnya secara tuntas. Kepuasan kerja memberikan kenyamanan bagi karyawan dalam bekerja. Upaya yang telah dilakukan oleh pihak PD Pasar Kabupaten Buleleng masih sangat kurang sehingga pengoptimalan peningkatan kepuasan kerja perlu dilakukan. Upaya peningkatan yang bisa dilakukan diantaranya peningkatan insentif dan bonus sesuai dengan standar kerja, memberikan penghargaan kepada karyawan berprestasi serta melaksanakan kegiatan bersama karyawan untuk meningkatkan kerjasama tim dan membangun tim yang solid setiap enam bulan sekali.

Bersumber capaian kalkulasi uji statistik analisis jalur dengan bantuan program SPSS 22.0 for Windows diperoleh yaitu Px1x2 =0,798, $\mathrm{p}$ value $=0,000<$ alpha 0,05 , sehingga diputuskan untuk menolak Ho. Artinya kemampuan kerja (X1) berdampak positif dan substansial terhadap kepuasan kerja (X2) PD Pasar, Paulin (Kabupaten Buleleng). Kontribusi kemampuan kerja (X1) terhadap kepuasan kerja (X2) sebesar 0,637 atau 63,7\%. Perihal ini sesuai dengan teori yang diuttarakan oleh Darmawan (2013) bahwa karyawan dengan kemampuan kerja yang sama akan mengharapkan kepuasan kerja sehingga kebutuhannya dapat terpenuhi. Capaian riset mendukung riset yang dilakukan oleh Suhaji (2015) yang menampakkan bahwa kemampuan kerja berdampak terhadap kepuasan kerja. Kemampuan kerja akan menunjang meningkatnya performa karyawan sehingga PD Pasar Kabupaten 
Buleleng perlu memberikan kepuasan kerja untuk memaksimalkan perihal tersebut. Capaian riset ini dibuktikan dari belum tercapainya standar performa yang telah ditetapkan PD Pasar Kabupaten Buleleng. Perihal ini disebabkan karena kurangnya kemampuan kerja dan ketidakpuasan karyawan dalam bekerja karena pihak PD Pasar Kabupaten Buleleng jarang memberikan intesentif dan penghargaan kepada karyawan sehingga perihal ini menimbulkan karyawan enggan dalam meningkatkan kemampuan kerja. Oleh karena itu, pihak PD Pasar Kabupaten Buleleng perlu segera melakukan perbaikan dan evaluasi terkait kemampuan kerja dan kepuasan kerja guna meningkatkan kualitas sumber daya manusia sehingga mencapai destinasi. Hal ini memberikan implikasi bahwa kemampuan kerja akan mendukung peningkatan performa karyawan, maka PD Pasar Buleleng perlu memberikan kepuasan kerja untuk mencapai destinasi tersebut sebesar-besarnya. Peningkatan performa karyawan dapat dilakukan dengan mengoptimalkan strategi yang terkait dengan variabel kemampuan kerja dan kepuasan kerja..

\section{Simpulan dan Saran}

Bersumber capaian dan pembahasan yang diakukan, dapat ditarik beberapa simpulan sebagai berikut: (1) Kemampuan kerja dan kepuasan kerja berdampak positif dan substansial terhadap performa karyawan PD Pasar Buleleng. Artinya kemampuan kerja dan kepuasan kerja berperan dalam meningkatkan performa karyawan PD Pasar Kabupaten Buleleng. (2) Kemampuan kerja berdampak positif dan substansial terhadap performa karyawan PD Pasar Buleleng. Artinya kemampuan kerja sangat berperan dalam meningkatkan performa karyawan PD Pasar Kabupaten Buleleng. (3) Kepuasan kerja berdampak positif dan substansial terhadap performa karyawan PD Pasar Buleleng. Artinya kepuasan kerja berperan dalam meningkatkan performa karyawan PD Pasar Kabupaten Buleleng. (4) Kemampuan kerja berdampak positif dan substansial terhadap kepuasan kerja di PD Pasar Buleleng. Artinya kemampuan kerja berperan dalam meningkatkan kepuasan kerja pada PD Pasar Buleleng.

Bersumber simpulan yang telah diuttarakan, maka dapat diiajukan beberapa saran yaitu: (1) Untuk pengurus PD Pasar Kabupaten Buleleng meningkatkan performa karyawan dengan memperhatikan variabel kemampuan kerja dan kepuasan kerja. Peningkatan kemampuan kerja melalui pelatihan dan pengembangan yang tepat serta pemberian kepuasan kerja melalui peningkatan insentif, bonus dan penghargaan kepada karyawan sangat tergantung dengan kebijakan manajemen perusahaan dan sumber daya manusia yang dimiliki. Untuk meningkatkan perihal tersebut pihak perusahaan perlu melakukan upaya evaluasi terhadap permasalahan internal. (2) Bagi pengkaji selanjutnya khususnya yang berminat untuk mengeksplorasi kemampuan kerja, kepuasaan kerrja dan performa karyawan, diiharapkan dapat mengembangkkan riset ini dengan menambahkan sample yang lebih luas untuk menguji kecurigaan kuat lainnya yang akan memdampaki variabel performa karyawan..

\section{Daftar Pustaka}

Arfida BR.2003. Ekonomi Sumber Daya Manusia,Jakarta,PT,Ghalia Indonesia.

Darmawan,D. 2013. Prinsip-prinsip prilaku Organisasi. Surabaya: Pena Semesta

Handoko, H. 2001. Manajemen Personalia dan Sumberdaya. Edisi II, Cetakan Keempat Belas Yogyakarta: BPFE

Hasibuan, H. Malayu SP . 2013. Manajemen SDM Masa Kini. Yogyakarta : Graha Ilmu.

Kuswanto, Dedy. 2012. Statistik Untuk Pemula Dan Orang Awan. Jakarta timur: Laskar Aksara.

Mangkunegara, A. P. 2011. Manajemen Sumber Daya Manusia Perusahaan. Edisi Kesepuluh. Bandung : PT Remaja Rosdakarya.

Martoyo, Susilo. 2006. Manajemen Sumber Daya Manusia. Edisi Kelima. Yogjakarta: BPFEYogjakarta. 
Mathis, Robert L dan Jhon H. Jackson. 2006. Manajemen Sumber Daya Manusia. Jakarta:Salemba Empat.

Paul, Hersey dan Kenneth H Blanchard. 1986. Manajemen Perilaku Organisasi Pendayagunaan Sumber Daya Manusia. Jakarta : Erlangga.

Putra, I Wayan Indra. 2014. "Pengaruh Tingkat Pendidikan dan Disiplin Kerja Terhadap Kinerja Karyawan”. E-journal Bisma Universitas Pendidikan Ganesha, Volume 4.

Rivai, V. 2009. Manajemen Sumber Daya Manusia untuk perusahaan dari Teori ke praktek. Jakarta: PT Raja Grafindo Persada

Robbins, Stephen P. 2015. Perilaku Organisasi. Edisi keenambelas. Jakarta : PT Indeks Gramedia.

Sajangbati,1. A. 2013. Pengaruh Motivasi,Disiplin,dan kepuasan kerja terhadap kinerja pegawai PT. Pos Indonesia (persero) Cabang Bitung. Jurnal EMBA Vol.1 No.4,667-678

Simamora, Hendry. 2004. Manajemen Sumber Daya Manusia. Edisi Ketiga. Yogyakarta : Bagian Penerbitan STIE YKPN.

Widodo,Joko,2004,Membangun Birokrasi Berbasis Kinerja,Banyumedia Publishing,Malang 